mgr inz. Sylwin Tomaszewski

mgr inż. Jerzy Frqczek

Instytut Pojazdów Szynowych ,TABOR”

\title{
Simulation tests of relay valve in the context of its resistances to motion
}

\begin{abstract}
The article presents the description of the cylinder relay valve designed and made by the Rail Vehicles Institute "TABOR". The individual components of its construction were characterized and it was selected those that have the significant influence on change of resistances to motion of the relay valve. The currently applicable criteria concerning the operating parameters of the cylinder relay valve are presented. The selected results of the tests which consisted in determining the impact of resistances to motion on change of the hysteresis values and the correctness of operation of the relay valve are presented. The stand, on which the simulation tests of relay valve operation were carried out, and the stand for measurements of resistances to motion are shown. The article also presents a computer simulation model in which the results were verified.
\end{abstract}

\section{Badania symulacyjne przekładnika ciśnienia w kontekście jego oporów ruchu}

\begin{abstract}
$W$ artykule przedstawiono opis przektadnika ciśnienia cylindrowego zaprojektowanego $i$ wykonanego przez Instytut Pojazdów Szynowych „TABOR”. Scharakteryzowano poszczególne elementy skladowe jego budowy oraz wytypowano te, które maja istotny wplyw na zmiane oporów ruchu przekładnika ciśnienia. Przedstawiono aktualnie obowiqzujqce kryteria dotyczqce parametrów działania przekładnika ciśnienia cylindrowego. Zaprezentowano wybrane wyniki badań, które polegaly na ustaleniu wpływu oporów ruchu na zmianę wartości histerezy oraz poprawności działania przektadnika ciśnienia. Pokazano stanowisko, na którym przeprowadzono badania symulacyjne działania przekładnika ciśnienia oraz stanowisko do pomiarów oporów ruchu. W artykule przedstawiono także komputerowy model symulacyjny, w którym weryfikowano wyniki badań.
\end{abstract}

1

WPROWADZENIE

Aby cały system hamulcowy funkcjonował prawidłowo na każdym pojeździe, wchodzącym w skład pociagu, musi znajdować się na nim odpowiednia aparatura odbierająca sygnały o hamowaniu bądź luzowaniu hamulców. Niezbędne jest także ujednolicenie, wymagań dla urządzeń sterujących i urządzeń wykonawczych w celu zapewnienia poprawności działania hamulców wszystkich wagonów w pociagu. Dotyczy to najbardziej odpowiedzialnych urządzeń hamulcowych, takich jak zawór rozrządczy i przekładnik lub przekładniki ciśnienia cylindrów hamulcowych, przyspieszacz hamowania nagłego, zawór ważący i układ przeciwpoślizgowy [1]. Wymagane parametry są zdefiniowane w odpowiednich kartach UIC i normach europejskich.

W artykule przedstawiono przykładowe wyniki badań przeprowadzonych na obiekcie rzeczywistym (przekładniku ciśnienia) jednego z czynników wpływu na osiagane przez niego parametry oraz wyniki badań symulacyjnych tego czynnika. Na podstawie uzyska-

\section{INTRODUCTION}

For correct functioning of the whole brake system on each vehicle included by the train, the appropriate apparatus receiving the signals of braking or releasing of the brakes must be on it. It is necessary to unify the requirements for control devices and executive devices to ensure the correct operation of the brakes of all wagons in the train. This concerns the most responsible braking equipment, such as the control valve and the relay or the relay valve of brake cylinders, the accelerator of emergency braking, the weighing valve and the anti-skid system [1]. The required parameters are defined in the suitable leaflets of UIC and European standards.

The paper presents the exemplary results of tests carried out on a real object (relay valve) of one of the factors that may affect the parameters achieved by it and the results of simulation tests of this factor. Based on the obtained results of tests the appropriate changes in the technical documentation of relays were put, which ensure that the current requirements during 
nych wyników badań wprowadzono odpowiednie zmiany $\mathrm{w}$ dokumentacji technicznej przekładników, które zapewniają spełnienie aktualnych wymagań w czasie eksploatacji oraz podwyższenie niezawodności jego działania, zapewniając wysoki stopień bezpieczeństwa eksploatowanych pojazdów.

\section{OPIS PRZEKLADNIKA CIŚNIENIA CY- LINDRÓW HAMULCOWYCH}

Przekładnik ciśnienia jest to aparat pneumatyczny służący do wzmacniania sygnału pneumatycznego o wymaganym (przez układ sterowania) ciśnieniu w cylindrze (-ach). Może być zainstalowany w pewnej odległości od zaworu rozrządczego na oddzielnym wsporniku albo na wspólnym wsporniku $\mathrm{z}$ zaworem rozrządczym (tzw. układ kompaktowy) lub na tablicy pneumatycznej pojazdu (wagonu).

Na rysunkach 1 i 2 przedstawiono przykładowe przekładniki z rodziny przekładników ciśnienia do napełniania cylindrów hamulcowych pojazdów i przewodu głównego zespołów trakcyjnych opracowane i wykonane w Instytucie Pojazdów Szynowych „TABOR". Przekładniki te są przeważnie montowane jako aparaty modułowe na hamulcowych tablicach pneumatycznych pojazdów szynowych.

W konstrukcji przekładnika (rys. 3) zastosowano szereg rozwiązań opartych na następujących elementach wykonawczych takich jak: tłoki uszczelnione membranami przenoszące odpowiednie siły, zaworki z gumowym pierścieniem uszczelniającym typu O-ring i typu U, sprężyny oraz precyzyjny układ tłoczkowo-suwakowy $\mathrm{z}$ przewijana membraną do płynnej zmiany ciśnienia w cylindrach w funkcji ładunku. W konstrukcji tego przekładnika przewidziano bardzo szeroki zakres regulacji jego parametrów w celu dopasowania jego charakterystyki do zróżnicowanych potrzeb pojazdów szynowych [2].

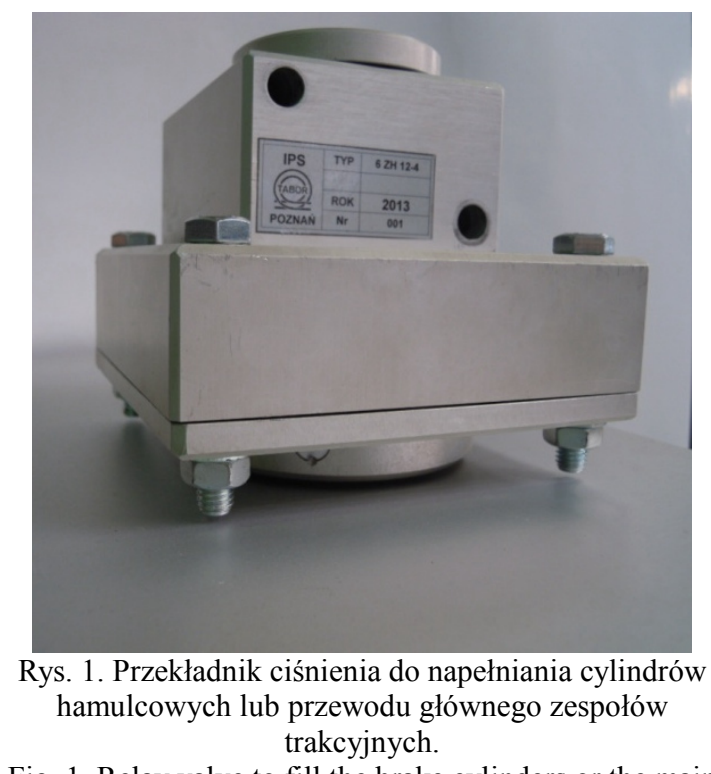

Fig. 1. Relay valve to fill the brake cylinders or the main pipe of the traction units. the operation are met and the reliability of its operation is increased, providing a high degree of safety of operated vehicles.

\section{DESCRIPTION OF RELAY VALVE OF BRAKE CYLINDERS}

The relay valve is a pneumatic device for amplifying the pneumatic signal with the required pressure (by the control system) in the cylinder (s). It can be installed at a certain distance from the control valve on a separate bracket or on a common bracket with the control valve (i.e. the compact system) or on the pneumatic board of the vehicle (wagon).

Figures 1 and 2 show the exemplary relays of the relay valves family to fill the brake cylinders of vehicles and the main pipe of the traction units, designed and made at the Rail Vehicles Institute "TABOR". These relay valves are usually mounted as the modular devices on the brake pneumatic boards of the rail vehicles.

In the construction of the relay valve (Fig. 3) a number of solutions are used based on the following executive elements such as pistons sealed with membranes carrying the appropriate forces, the valves with a rubber sealing ring of type O-ring and $U$, the spring and a precise piston -slide system with the scrolled membrane to a smooth change of pressure in cylinders in a function of load. In the construction of the relay valve, a very wide range of adjustment of its parameters to match its characteristic to the diverse needs of rail vehicles are predicted [2].

The main element of relay valve consists of a hollow shaped rod (8) connected to the pistons (5) and the membranes (6). It moves in the body (1) up or down depending on the pressure difference occurring on two sides of the membrane. For each relay valve the supply air is permanently supplied $(Z)$ from the

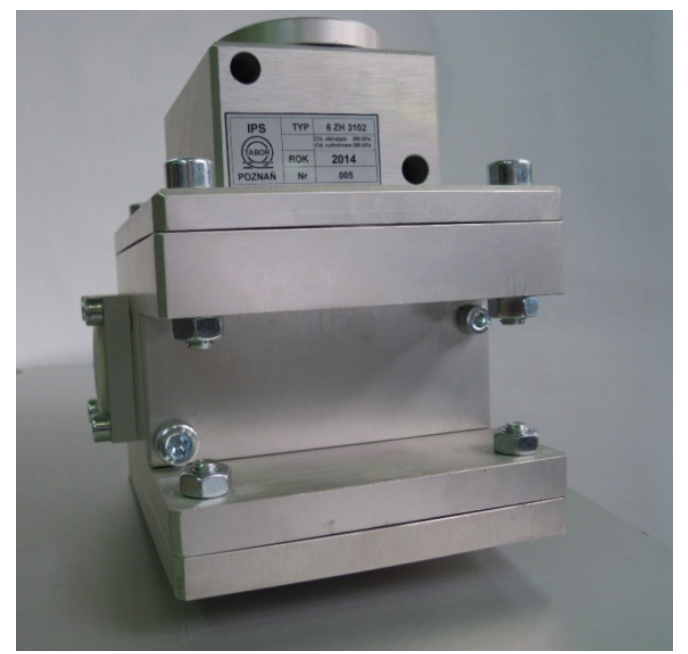

Rys. 2. Przekładnik ciśnienia do napełniania cylindrów hamulcowych o regulowanym przełożeniu.

Fig. 2. Relay valve to fill the brake cylinders with the adjustable ratio. 
Główny element przekładnika ciśnienia składa się z wyprofilowanego trzonu drążonego (8) połączonego z tłokami (5) i membranami (6). Porusza się on w korpusie (1) w górę lub w dół zależnie od różnicy ciśnień występującej po dwóch stronach membrany. Do każdego przekładnika stale jest dostarczane powietrze zasilające $(\mathrm{Z})$ ze zbiorników pomocniczych. Gdy zawór rozrządczy wygeneruje sygnał sterujący (S) do komory pod dolnym tłokiem dochodzi do przesunięcia w górę trzonu i otwarcia zaworka (2), co pozwala na przedostanie się powietrza zasilającego na stronę wyjściową przekładnika (C) zasilającą pojemność cylindra hamulcowego.

W sytuacji odwrotnej, gdy maleje sygnał sterujący (S), zaworek zamyka dopływ z zasilania (Z), a powietrze znajdujące się po stronie wyjściowej (C) przekładnika uchodzi z cylindra do atmosfery poprzez trzon drążony [2].

Aby przekładniki ciśnienia o skomplikowanej budowie, zwłaszcza te $\mathrm{z}$ regulowanym przełożeniem $\mathrm{i}$ mechaniczno - pneumatycznym układem zmiany sygnału obciążenia spełniły stawiane im wymagania istotne jest bardzo dokładne wykonanie ich podzespołów oraz staranny montaż i regulacja. W związku z zaobserwowaniem pewnego rozrzutu parametrów przekładników zaistniała potrzeba przeprowadzania szczegółowych badań, w tym symulacyjnych, pozwalających na ustalenie czynników wpływu i na optymalizację konstrukcji w celu zapewnienia jak największej powtarzalności i niezawodności działania przekładników ciśnienia.

\section{ELEMENTY PRZEKLADNIKA MAJĄCE ISTOTNY WPLYW NA ZMIANE JEGO OPORÓW RUCHU}

$\mathrm{Na}$ rysunku 4 przedstawiono schemat budowy przekładnika ciśnienia, na którym wymieniono poszczególne układy:

1. Układ zaworka trójdrogowego - składający się $\mathrm{z}$ korpusu $\mathrm{z}$ siedziskiem, zaworka $\mathrm{z}$ uszczelnieniami gumowymi oraz ze sprężyny,

2. Układ tłoka górnego - składający się z korpusu, trzona drazżonego, tłoka oraz membrany,

3. Układ mechaniczny - składający się z korpusu, dźwigni górnej i dolnej, rolki oraz podpór będących punktami obrotu dźwigni

4. Układ tłoka dolnego - składający się z korpusu oraz tłoka z membraną.

Wielokrotne obserwacje podczas odbiorów jakościowych przekładników ciśnienia pozwoliły na wytypowanie układu mechanicznego jako głównego elementu mającego wpływ na sprawność przekładnika ciśnienia. Dodatkowo przeprowadzone badania i pomiary wykazały, że elementem mającym istotny wpływ na sprawność są poprawnie wykonane podpory dźwigni. W związku z tym przeprowadzono pomiary auxiliary tanks. When the control valve generates a control signal (S) to the chamber beneath the bottom piston, the rod moves up and valve is opened (2), which allows the supply air to get to the output side of the relay valve (C) supplying the brake cylinder capacity.

In the opposite situation when the control signal decreases (S), the valve shuts off the flow of supply (Z) and the air from the output side (C) of the relay valve flows from the cylinder to the atmosphere through the hollowed rod [2].

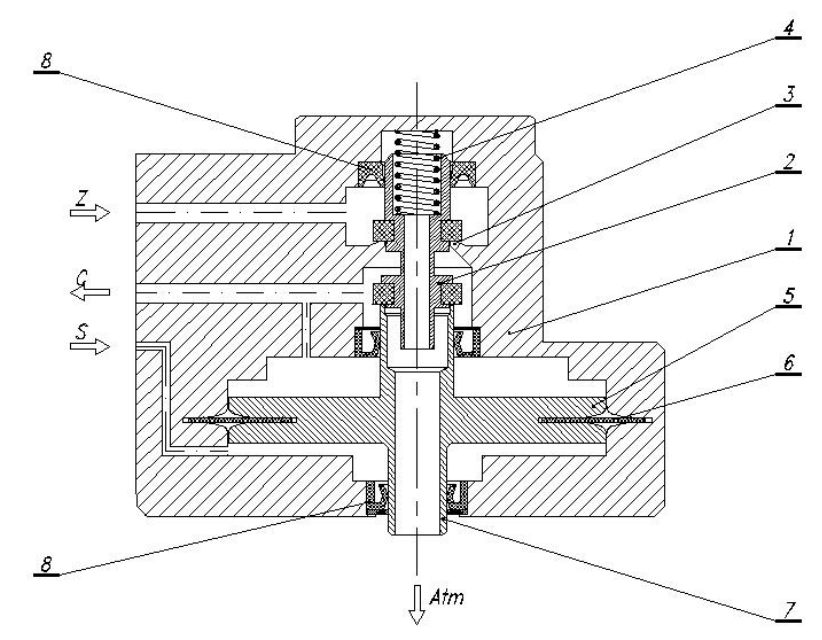

Rys. 3. Schemat działania jednostopniowego przekładnika ciśnienia opracowanego przez IPS „TABOR” : Z - zbiornik pomocniczy, C - cylinder, S - sygnał sterujący, 1 - korpus przekładnika, 2 - zaworek napełniający, 3 - siedzisko zaworka, 4 - sprężyna, 5 - tłok, 6 - membrana, 7 - trzon drążony, 8 pierścień uszczelniający.

Fig. 3. Diagram of one-stage relay valve developed by the IPS „TABOR" : Z - auxiliary tank, C - cylinder, $\mathrm{S}$ - control signal, 1 relay valve body, 2 - filling valve, 3 - valve seat, 4 - spring, 5 piston, 6 - membrane, 7 - hollow rod, 8 - sealing ring.

To relay valves with the complicated construction, especially those with adjustable ratio and mechanical - pneumatic system of the load signal changes meet the requirements put them it is important to make very precisely their subassemblies and the careful assembly and adjustment. In connection with the observation of a scattering of relay valve parameters there was a need to carry out the detailed tests, including simulation, allowing to determine the factors of influence and optimize the construction in order to provide the largest possible reproducibility and reliability of the relay valves.

\section{COMPONENTS OF RELAY VALVE HAVING THE SIGNIFICANT IMPACT ON CHANGE OF ITS RESISTANCES TO MOTION}

Figure 4 shows a diagram of the relay valve construction in which the individual systems are listed:

1. System of three - way valve consisting of the body with seat, the valve with rubber sealing 
kilkudziesięciu podpór dźwigni. Na tej podstawie ustalono najczęściej występującą wadę wykonania podpór. Wada ta polegała na niezachowaniu równoległości krawędzi styku podpory z dźwignią do powierzchni styku podpory $\mathrm{z}$ korpusem. Na rys. 5 pokazano $\mathrm{w}$ sposób poglądowy podporę wykonaną $\mathrm{z}$ niezachowaniem wyżej opisanej równoległości.

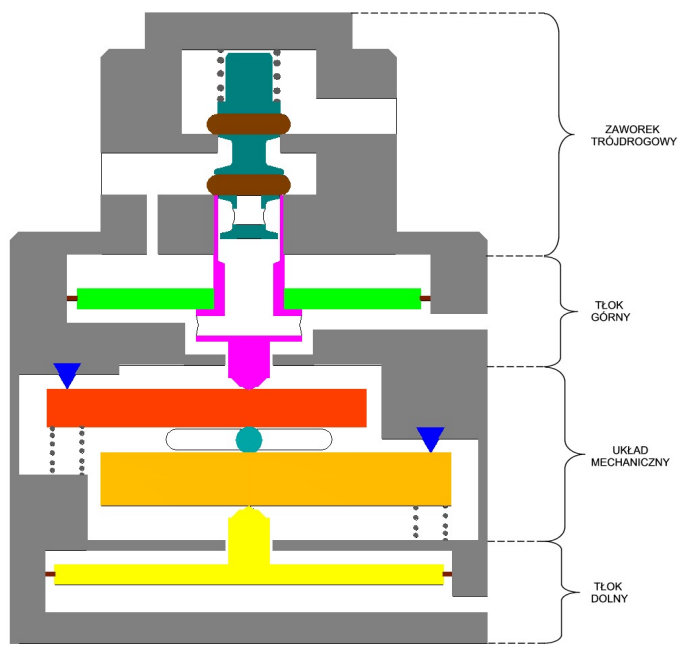

Rys. 4. Schemat budowy przekładnika ciśnienia z podziałem na główne układy

Fig. 4. Diagram of relay valve construction with the division into the main systems
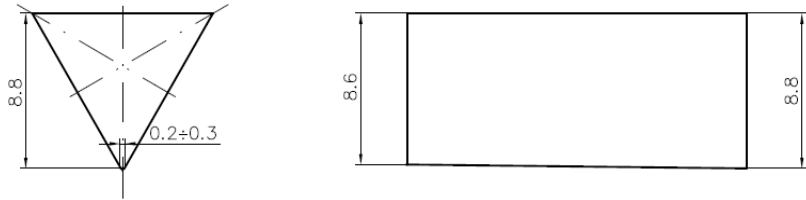

Rys. 5. Rysunek podpory dźwigni wykonanej z niezachowaniem równoległości

Fig. 5. Drawing of lever's support made with no maintain of parallelism

W trakcie badań zmierzono siły tarcia występujące w układzie mechanicznym przekładnika ciśnienia. W tym celu zbudowano stanowisko, na którym za pomocą czujnika siły, mierzono rzeczywiste siły przenoszone na układ mechaniczny poprzez tłok dolny przekładnika sterowany pneumatycznie na tłok górny. Widok tego stanowiska pokazano na rys. 6 .

Badania przeprowadzono na egzemplarzu przekładnika ciśnienia bez opisanych wyżej wad typu 6ZH 56-1 traktując go jako bazę do dalszych analiz, oraz na czterech przekładnikach tego samego typu, ale o różnym, nieprawidłowym wykonaniu podpór dźwigni, powodującym powstanie nierównoległości w układzie dźwigniowym. Na rysunkach nr 7 i 8 przedstawiono przykładowe przebiegi z pomierzonych sił występujących w układzie mechanicznym przekładnika podczas quasi statycznego wzrostu i malenia ciśnienia sterującego dla przekładnika bazowego i o największej nierównoległości podpór.

Pomiar sił przy wzroście i przy spadku ciśnienia pozwolił na wyznaczenie oporów ruchu jakie występują w układzie mechanicznym przekładnika ciśnienia i sprawności przekładnika. and the spring,

2. System of upper piston - consisting of the body, the hollow rod, the piston and the membrane,

3. Mechanical system - consisting of the body, the upper and lower lever, the roller and the supports being the points of lever's turn

4. System of lower piston - consisting of the body and the piston with membrane.

The repeated observations during the quality acceptance of relay valves allowed to select a mechanical system as the main element affecting the efficiency of the relay valve. In addition, the carried out tests and measurements showed that the correctly made supports of lever were the element having a significant impact on efficiency. Therefore, the measurements of several dozen supports of lever were carried out. On this basis, the most common defect of making the supports was determined. This defect consisted in no maintain of edges parallelism of the contact of support with the lever to the contact surface of the support with the body. Fig. 5 shows in a visual way of the support made with no maintain of parallelism described above.

During the tests the friction forces occurring in the mechanical system of the relay valve were measured. For this purpose the stand was built, in which by means of a force sensor, the actual forces carried on the mechanical system by the lower piston of the relay valve controlled pneumatically on the upper piston were measured. The view of this stand is shown in Fig. 6

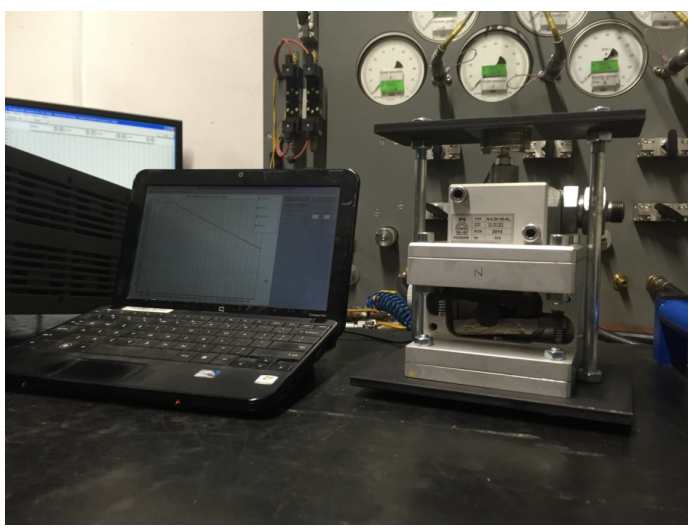

Rys. 6. Widok stanowiska do pomiaru sił w układzie mechanicznym przekładnika ciśnienia.

Fig. 6. View of the stand for measuring the forces in the mechanical system of the relay valve

Tests were carried out on a specimen of the relay valve without the described above faults of type 6ZH 56-1 treating it as a base for the further analysis, and on four relay valves of the same type, but with different, incorrect making of the lever's supports causing occurrence of no parallelism in the lever system. Figures 7 and 8 show the exemplary courses of the measured forces occurring in the mechanical system of the relay valve during the quasi-static 


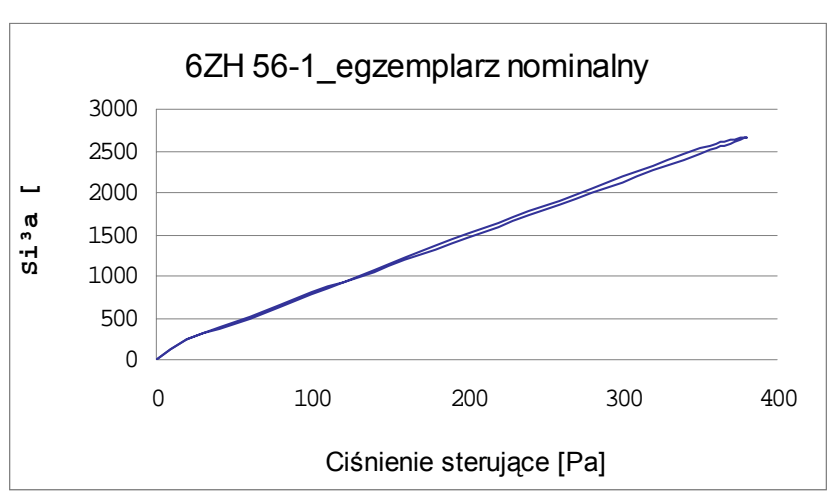

Rys. 7. Przebieg sił w przekładniku bazowym

Fig. 7. Course of forces in the basic relay valve

\section{ANALIZA OBOWIACCUJACYCH KRYTE- RIÓW DZIALANIA PRZEKLADNIKÓW CIŚNIENIA}

Do podstawowych kryteriów oceny prawidłowego działania przekładników ciśnienia, poza realizowaniem hamowania i odluzowywania układu, należy zaliczyć histerezę oraz czułość działania przekładników ciśnienia. Histerezę przedstawia się najczęściej na wykresie dwóch zależnych od siebie wielkości w postaci pętli histerezy, co przedstawiono na rys. 9.

Pod pojęciem histerezy przekładnika ciśnienia rozumie się różnicę ciśnienia cylindrowego (wyjściowego) dla tej samej wartości ciśnienia sterującego (wejściowego), przy czym raz ciśnienie sterujące wzrasta do zadanej wartości, a w drugim przypadku spada do wartości zadanej. Tak określona histereza przekładnika ciśnienia jest wielkością wyrażoną $\mathrm{w}$ $\mathrm{kPa}(1)$.

gdzie:

$$
H=P_{2}-P_{1}
$$

$P_{1}$ - ciśnienie wyjściowe przy spadku ciśnienia wejściowego,

$P_{2}$ - ciśnienie wyjściowe przy wzroście ciśnienia wejściowego.

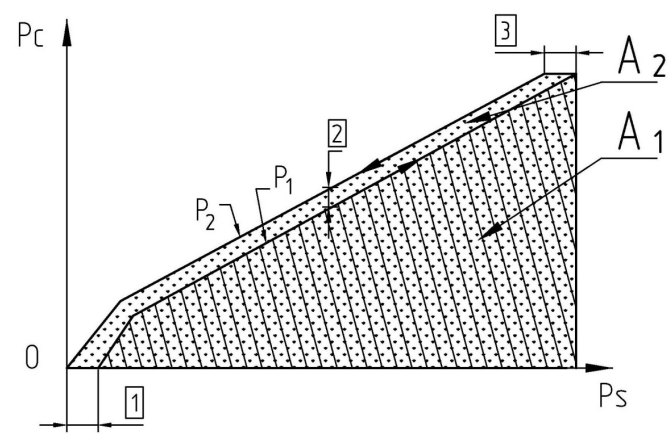

Rys. 9. Wykres obrazujący histerezę i czułość przekładnika ciśnienia.

(1- czułość inicjacyjna, 2 - histereza, 3 - czułość odwrócona, $\mathrm{p}_{\mathrm{s}}$ ciśnienie wejściowe, $\mathrm{p}_{\mathrm{c}}$ - ciśnienie wyjściowe. [1])

Fig. 9. Graph presenting the hysteresis and sensitivity of relay valve. 1- initiation sensitivity, 2 - hysteresis, 3 - reversed sensitivity, $\mathrm{p}_{\mathrm{s}}-$ input pressure, $\mathrm{p}_{\mathrm{c}}-$ output pressure. [1] increase and decrease of the control pressure for the basic relay valve and with the highest no parallelism of the supports.

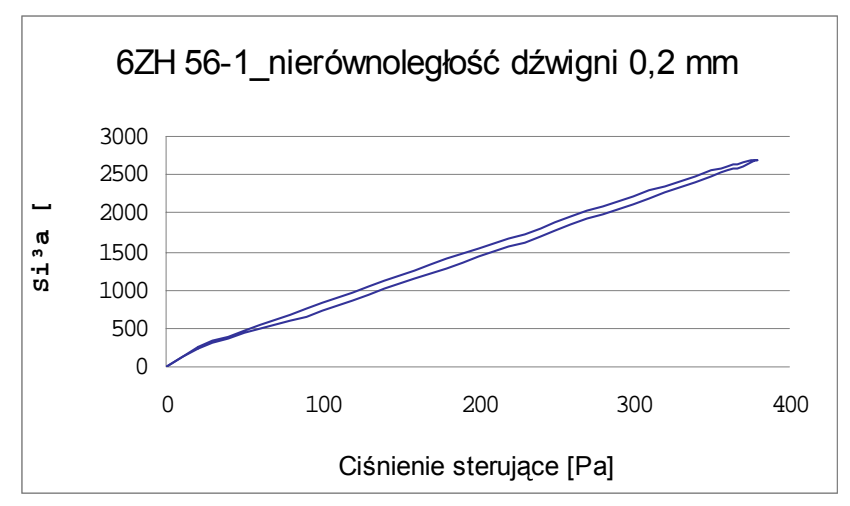

Rys 8. Przebieg sił w przekładniku o nierównoległości dźwigni równej $0,2 \mathrm{~mm}$.

Fig 8. Course of forces in the relay valve with no parallelism of lever of $0,2 \mathrm{~mm}$.

The measurement of forces with the increase and drop of the pressure allowed to determine the resistances to motion which occur in the mechanical system of relay valve and efficiency of the relay valve.

\section{ANALYSIS OF APPLICABLE CRITERIA OF RELAY VALVE OPERATION}

The hysteresis and operation sensitivity of relay valves should be included to the basic criteria for assessment of the correct operation of the relay valve, apart from the braking realizing and system releasing. Most often the hysteresis is presented in the graph of two dependent on each other quantities as a hysteresis loop as shown in Fig. 9.

Under the term of relay valve hysteresis is meant a difference of cylinder pressure (output) for the same value of the controlling pressure (input), in addition once the controlling pressure increases to a set value, and in the second case it falls to the set value. The hysteresis of relay valve determined in this way is the quantity expressed in $\mathrm{kPa}(1)$.

where:

$$
H=P_{2}-P_{1}
$$

$P_{1}$ - output pressure when the input pressure drops $P_{2}$ - output pressure when the input pressure increases

The size of the hysteresis (losses) of relay valve can be assessed with the dimensionless quantity called the efficiency of relay valve (2).

$$
\eta=\frac{A_{1}}{A_{2}}
$$

where:

$A_{1}$ - area under the curve showing the pressure increase

$A_{2}$ - area under the curve showing the pressure drop 
Można również ocenić wielkość histerezy (strat) przekładnika bezwymiarową wielkością zwaną sprawnością przekładnika ciśnienia (2).

$$
\eta=\frac{A_{1}}{A_{2}}
$$

gdzie:

$A_{1}$ - pole powierzchni pod krzywą obrazującą wzrost ciśnienia,

$A_{2}$ - pole powierzchni pod krzywą obrazującą spadek ciśnienia.

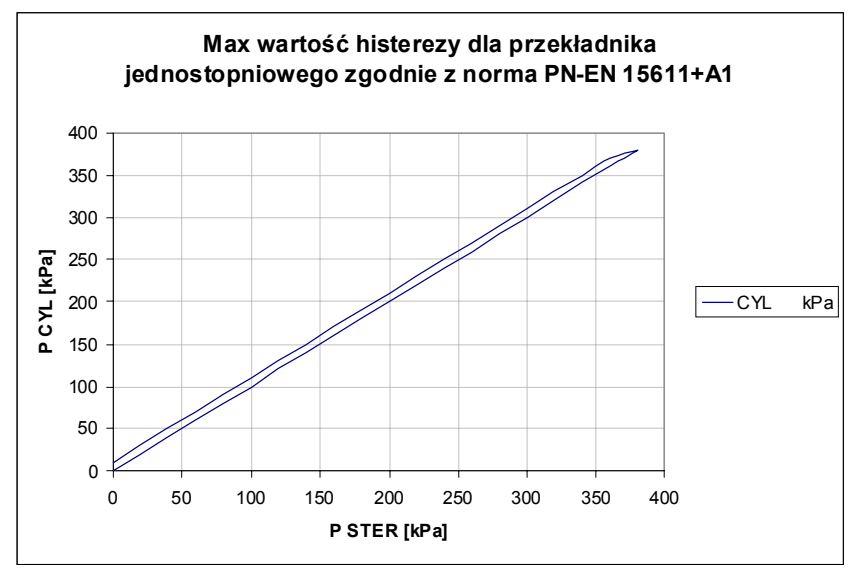

Rys. 10. Wymagana wartość histerezy dla jednostopniowego przekładnika ciśnienia.

Fig. 10. The required value of hysteresis for the one-stage relay valve.

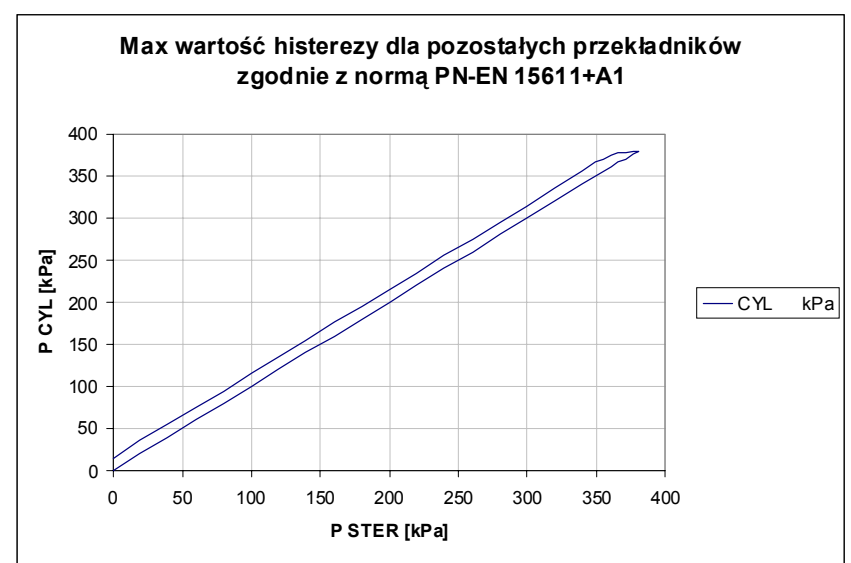

Rys. 11. Wymagana wartość histerezy dla przekładników ciśnienia innych niż jednostopniowe.

Fig. 11. The required value of hysteresis for the relay valves different than one-stage ones.

Zgodnie z normą [3] na rysunkach 10 i 11 przedstawiono, w postaci graficznej, wymagane wartości histerezy dla przekładników ciśnienia. Natomiast na rys. 12 zaprezentowano przykładowy przebieg ciśnień, na którym przedstawiono hamowanie i luzowanie pełne, hamowanie i luzowanie stopniowe oraz próbę czułości dla niskiego i wysokiego ciśnienia cylindrowego.

Zgodnie ze wzorami (1) i (2) wyznaczono następujące wymagane wartości histerezy: - jednostopniowe przekładniki ciśnienia (rys. 10):

$$
\begin{gathered}
H=10 \mathrm{kPa} \\
\eta_{(\mathrm{w})}=0,9512
\end{gathered}
$$

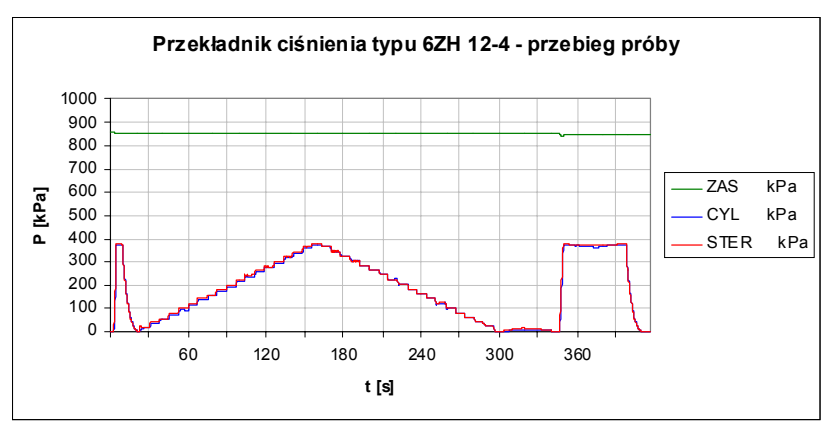

Rys. 12. Przebieg ciśnień cylindrowych jednostopniowego przekładnika ciśnienia typu 6ZH 12-4.

Fig. 12. Course of cylinder pressures of the one-stage relay valve of type $6 \mathrm{ZH} 12-4$.

According to the standard [3] figures 10 and 11 show, in the graphic form, the required values of hysteresis for the relay valves. However, fig. 12 presents the exemplary course of pressures, which shows the braking and complete releasing, braking and gradual releasing and test of sensitivity for the low and high cylinder pressure.

According to formulas (1) and (2) the following required values of hysteresis were determined:

- one-stage relay valves (fig. 10):

$$
\begin{gathered}
H=10 \mathrm{kPa} \\
\eta_{(\mathrm{w})}=0,9512
\end{gathered}
$$

- other relay valves (fig. 11):

$$
\begin{gathered}
\mathbf{H}=15 \mathrm{kPa} \\
\eta_{(\mathrm{w})}=0,9286
\end{gathered}
$$

Due to the fact that the course of the hysteresis loop for braking and gradual releasing in fact differs from the static reference course presented in figures 10 and 11, it is impossible to determine the value of the hysteresis $\mathrm{kPa}$ explicitly. Therefore, it was decided to determine the hysteresis of relay valve only on the basis of the dimensionless quantity according to formula 2 and fig. 9 .

\section{INFLUENCE OF RESISTANCES TO MOTION ON THE RELAY VALVE OPERATION}

The tests aimed at the determination of the forces occurring in a mechanical system of relay valve as a result of no perpendicularity of supports of the lever system showed that there is a close relation between the quality of performance of these supports and the size of the resistances to motion in the relay valve. The resistances are presented graphically in the form of hysteresis loop for the measured forces in chapter 3.

After analyzing the changes that occurred in the measured forces, it was decided to check the impact of no perpendicularity of the made supports to the overall operation of relay valves. Therefore, 10 pieces of relay valves for each support were tested with a specific no perpendicularity of making ( 0.05 $\mathrm{mm}, 0.10 \mathrm{~mm}, 0.15 \mathrm{~mm}$ and $0.20 \mathrm{~mm}$ ). Fig. 13 shows the exemplary courses of the hysteresis loop of the cylinder pressure for the supports made correctly, but 
- pozostałe przekładniki ciśnienia (rys. 11):

$$
\begin{gathered}
H=15 \mathrm{kPa} \\
\eta_{(\mathrm{w})}=0,9286
\end{gathered}
$$

$\mathrm{Z}$ uwagi na fakt, że przebieg pętli histerezy dla hamowania i luzowania stopniowego w rzeczywistości odbiega od statycznego wzorcowego przebiegu przedstawionego na rysunkach 10 i 11 , niemożliwe jest jednoznaczne określenie wartości histerezy w $\mathrm{kPa}$. W związku z tym postanowiono określać histerezę przekładnika ciśnienia tylko $\mathrm{w}$ oparciu o wielkość bezwymiarową zgodnie ze wzorem 2 i rys. 9.

\section{WPLYW OPORÓW RUCHU NA DZIALA- NIE PRZEKLADNIKA CIŚNIENIA}

Badania mające na celu wyznaczenie sił występujących w układzie mechanicznym przekładnika ciśnienia na skutek nieprostopadłości podpór układu dźwigniowego pokazały, że zachodzi ścisła zależność między jakością wykonania tych podpór a wielkością oporów ruchu w przekładniku ciśnienia. Opory te zaprezentowano w sposób graficzny, w postaci pętli histerezy dla zmierzonych sił, w rozdziale 3.

Po przeanalizowaniu zmian, jakie powstały $\mathrm{w}$ mierzonych siłach, postanowiono sprawdzić wpływ nieprostopadłości wykonanych opór na ogólne działanie przekładników ciśnienia. W związku z tym przebadano po 10 szt. przekładników dla każdej

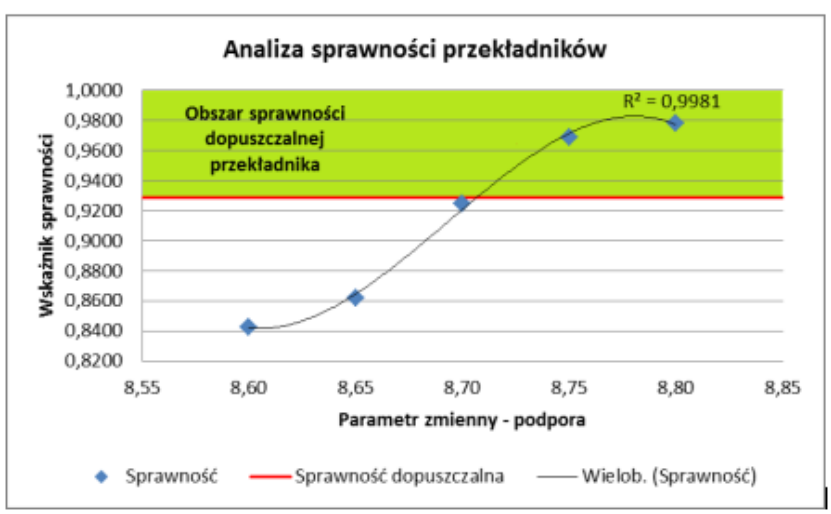

Rys. 15. Analiza sprawności przekładników dla poszczególnych podpór w odniesieniu do sprawności dopuszczalnej

Fig. 15. Analysis of relay valves efficiency for the individual supports with reference to the acceptable efficiency in Fig. 14 is the course of pressures for the supports with no parallelism of $0.20 \mathrm{~mm}$.

Table 1 presents list of efficiency coefficients $\eta$ for all tested relay valves and all kinds of supports, and in fig. 15 they are compared with the acceptable index for the whole relay valve, given in the standard [3].

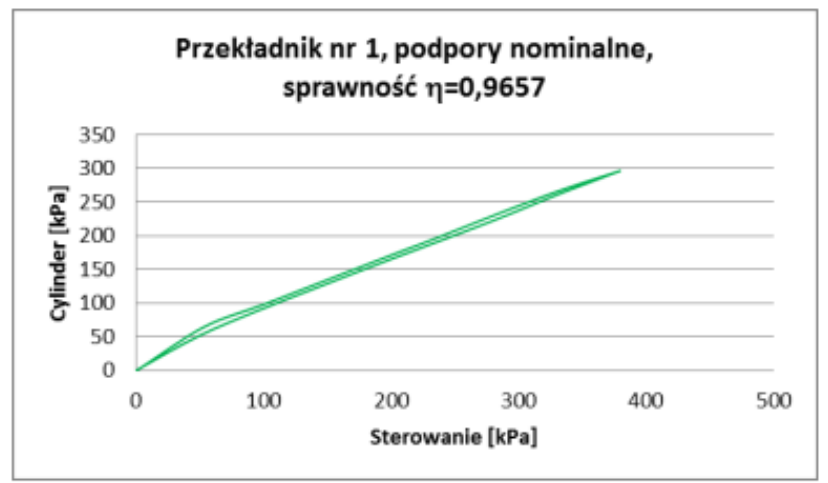

Rys. 13. Przykładowy przebieg pętli histerezy dla przekładnika nr $1 \mathrm{z}$ podporami wykonanymi bez wad

Fig. 13. Exemplary course of hysteresis loop for relay valve No 1 with the supports made without defects

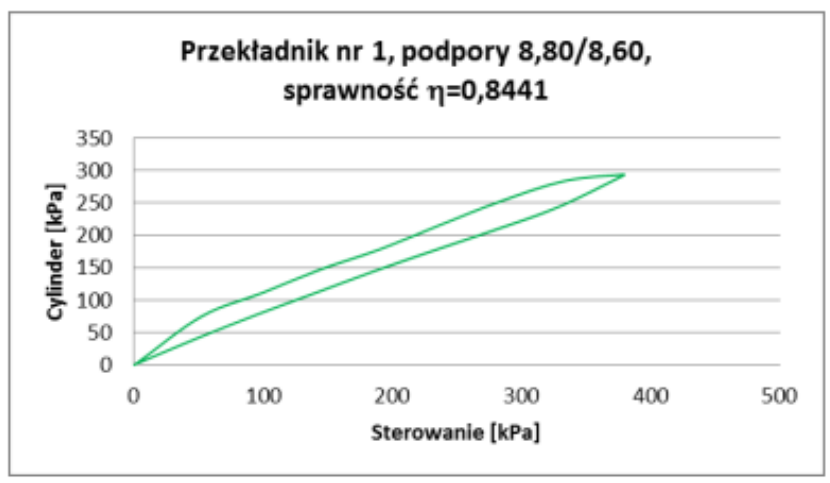

Rys. 14. Przykładowy przebieg pętli histerezy dla przekładnika nr $1 \mathrm{z}$ podporami o nierównoległości $0,2 \mathrm{~mm}$

Fig. 14. Exemplary course of hysteresis loop for relay valve No 1 with the supports with no parallelism of $0,2 \mathrm{~mm}$

Tablica 1. Zestawienie wskaźników sprawności $\eta$ dla badanych przekładników z poszczególnymi podporami Table 1. List of efficiency coefficients $\eta$ for the tested relay valves with the individual supports

\begin{tabular}{|r|c|c|c|c|c|c|c|c|c|c|r|}
\hline & \multicolumn{9}{|c|}{ Numer przekładnika } & \\
\hline $\begin{array}{c}\text { Typ } \\
\text { podpory }\end{array}$ & $\mathbf{1}$ & $\mathbf{2}$ & $\mathbf{3}$ & $\mathbf{4}$ & $\mathbf{5}$ & $\mathbf{6}$ & $\mathbf{7}$ & $\mathbf{8}$ & $\mathbf{9}$ & $\mathbf{1 0}$ & ŚREDNIA \\
\hline $\mathbf{8 , 8 0}$ & 0,9657 & 0,9788 & 0,9750 & 0,9772 & 0,9787 & 0,9850 & 0,9747 & 0,9753 & 0,9869 & 0,9820 & $\mathbf{0 , 9 7 7 9}$ \\
\hline $\mathbf{8 , 7 5}$ & 0,9552 & 0,9706 & 0,9608 & 0,9661 & 0,9710 & 0,9781 & 0,9639 & 0,9682 & 0,9794 & 0,9761 & $\mathbf{0 , 9 6 8 9}$ \\
\hline $\mathbf{8 , 7 0}$ & 0,9095 & 0,9274 & 0,9217 & 0,9232 & 0,9282 & 0,9295 & 0,9150 & 0,9271 & 0,9300 & 0,9340 & $\mathbf{0 , 9 2 4 6}$ \\
\hline $\mathbf{8 , 6 5}$ & 0,8441 & 0,8713 & 0,8621 & 0,8599 & 0,8716 & 0,8682 & 0,8447 & 0,8681 & 0,8640 & 0,8660 & $\mathbf{0 , 8 6 2 0}$ \\
\hline $\mathbf{8 , 6 0}$ & 0,8304 & 0,8542 & 0,8386 & 0,8392 & 0,8483 & 0,8512 & 0,8303 & 0,8495 & 0,8402 & 0,8438 & $\mathbf{0 , 8 4 2 6}$ \\
\hline
\end{tabular}


podpory z określoną nieprostopadłością wykonania $(0,05 \mathrm{~mm}, 0,10 \mathrm{~mm}, 0,15 \mathrm{~mm}$ oraz $0,20 \mathrm{~mm})$. Na rys. 13 przedstawiono przykładowe przebiegi pętli histerezy ciśnienia cylindrowego dla podpór wykonanych prawidłowo natomiast na rys. 14 znajduje się przebieg ciśnień dla podpór z nierównoległością $0,20 \mathrm{~mm}$.

W tabeli 1 przedstawiono zestawienie współczynników sprawności $\eta$ dla wszystkich badanych przekładników i wszystkich rodzajów podpór, a na rys. 15 porównano je ze wskaźnikiem dopuszczalnym, dla całego przekładnika ciśnienia, podanym $\mathrm{w}$ normie [3].

6 MODEL SYMULACYJNY PRZEKLADNIKA CIŚNIENIA JAKO NARZĘDZIE DO WERYFIKACJI WYNIKÓW BADAŃ JEGO SPRAWNOŚCI W FUNKCJI OPORÓW RUCHU

W celu potwierdzenia hipotezy założonej podczas badań opisanych w rozdziałach 3 i 4, postanowiono opracować matematyczny model symulacyjny, w którym byłaby możliwość zadawania dowolnych oporów ruchu powstających $\mathrm{w}$ różnych miejscach i obserwacji ich wpływu na wartość histerezy działania przekładnika ciśnienia. Do opracowania takiego modelu wykorzystano arkusz kalkulacyjny Excel, a do doboru parametrów liczbowych wykorzystano dokumentację konstrukcyjną przekładnika oraz parametry uzyskane podczas prób przeprowadzanych na stanowiskach badawczo - odbiorczych w IPS "TABOR".

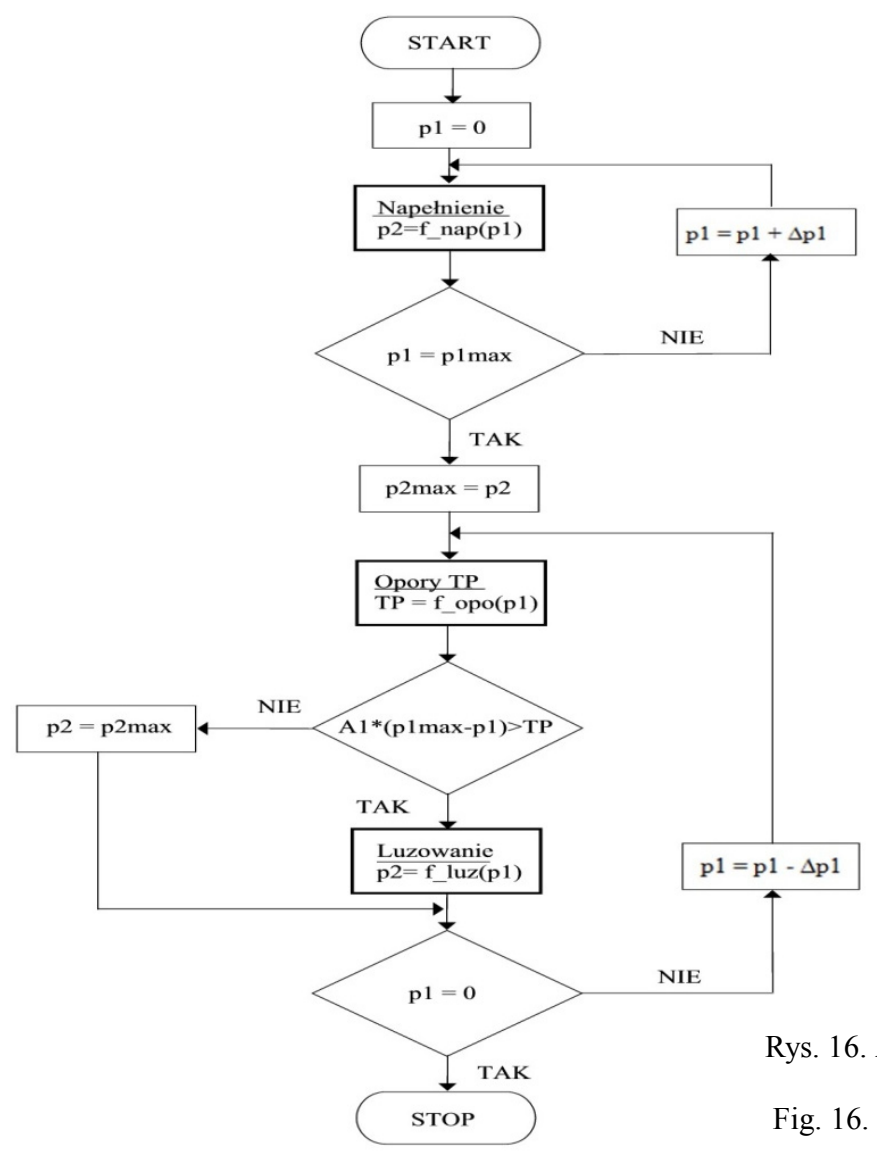

Fig. 16. The algorithm of program working to simulate the relay
Area of the acceptable efficiency presented in Fig. 15 Includes the efficiency of the whole relay valve, and therefore the efficiency of the three-way valve, the upper piston, the mechanical system and the lower piston. Because of this, it can be assumed that for the mechanical system of relay valve may use only half of this area. Therefore, to provide the correct operation of the relay valve it can be assumed the acceptable defectiveness of supports (no parallelism) of max. $0.05 \mathrm{~mm}$. The bigger no parallelism causes the appearance of transverse forces which cause the friction forces in the piston axis, which strongly reduces the efficiency of the relay valve.

6 SIMULATION MODEL OF RELAY VALVE AS A TOOL FOR VERIFICATION OF TESTS RESULTS OF ITS EFFICIENCY IN THE FUNCTION OF RESISTACES TO MOTION

In order to confirm the hypothesis assumed during the tests described in chapters 3 and 4, it was decided to develop a mathematical simulation model, in which it would be the opportunity to give any resistances to motion occurring in different places and observe their impact on the value of the hysteresis of the relay valve operation. To develop such a model the Excel spreadsheet was used, and for selection of numerical parameters used in the design documentation of the relay valve and parameters obtained during the tests carried out on the at research - acceptable in the IPS "TABOR" were used.

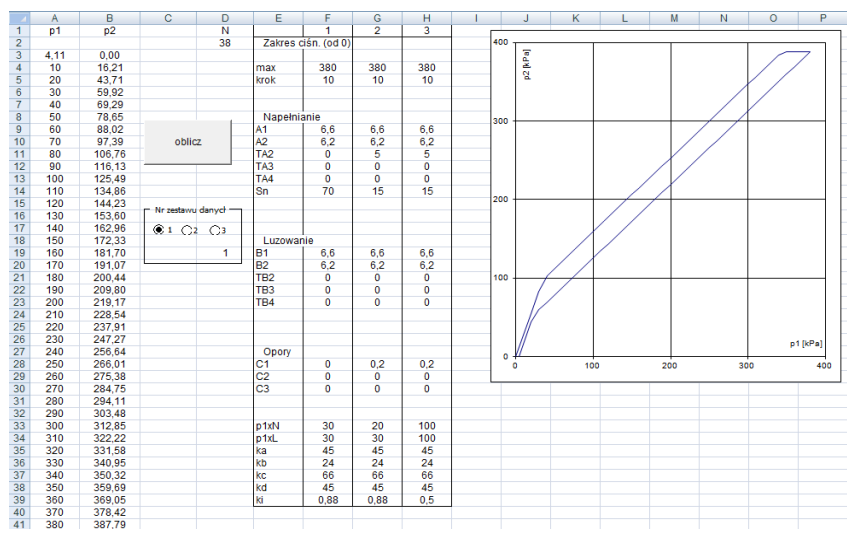

Rys. 17. Widok ekranu symulacji działania przekładnika ciśnienia (dane wejściowe i wynik symulacji)

Fig. 17. Screen view of simulation of relay valve operation (input data and simulation result) 
$\mathrm{Na}$ rys. 16 przedstawiono ogólny algorytm działania programu do symulacji przekładnika ciśnienia a na rys. 17 pokazano przykładowy zapis danych wejściowych i końcowy wynik symulacji.

Na rys. 18 i 19 przedstawiono przykładowe przebiegi pętli histerezy działania przekładnika ciśnienia otrzymany z modelu symulacyjnego z założeniem oporów ruchu będących wynikiem wyznaczonych sił powstałych na skutek nierównoległości podpór dźwigni (zgodnie z rys. 7 i 8). Porównanie sprawności otrzymanej z wyników badań i sprawności z modelu symulacyjnego pozwala na stwierdzenie, że model symulacyjny odzwierciedla stan rzeczywisty z dokładnością do ok $98 \%$.

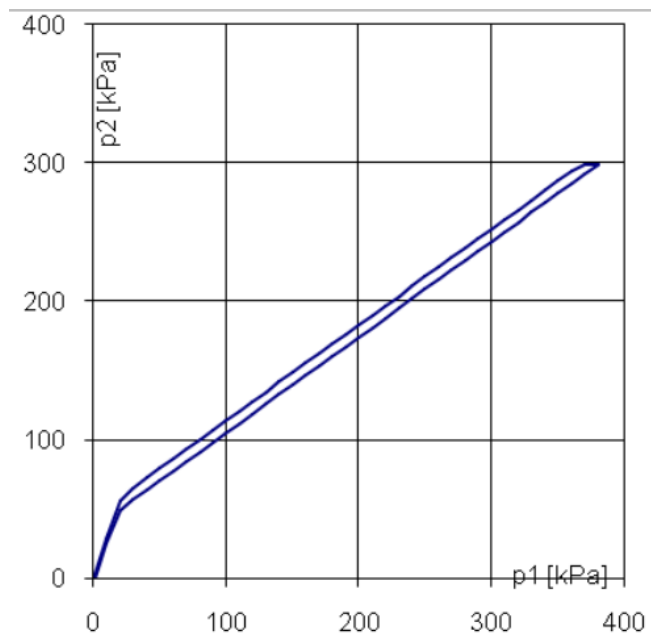

Rys. 18. Przebieg pętli histerezy w modelu symulacyjnym dla oporów ruchu z rys. 7 . Sprawność $\eta=\mathbf{0 , 9 5 1 0}$

Fig. 18. Course of the hysteresis loop in the simulation model for the resistances to motion from fig. 7. Efficiency $\eta=\mathbf{0 , 9 5 1 0}$

\section{PODSUMOWANIE}

Na podstawie przeprowadzonych prób ustalono jedną z przyczyn powstawania zwiększonej histerezy przekładnika ciśnienia, dzięki czemu zawężono tolerancję wykonania podpór dźwigni, zapewniając tym samym zadowalającą powtarzalność działania przekładników nowych i pozostających w eksploatacji.

Opracowano matematyczny model symulacyjny przekładnika, dzięki któremu można było wyodrębnić różne czynniki wpływu na jego sprawność. Dzięki wynikom badań prowadzonym na modelu symulacyjnym wprowadzono szereg innych zmian optymalizacyjnych w dokumentacji technicznej przekładnika zapewniających wymagana czułość i histereze przekładników ciśnienia.

\section{Bibliografia}

[1] Kaluba M.: Przekładnik ciśnienia z automatycznq zmianq ciśnienia cylindrowego w funkcji ładunku dla pojazdów szynowych. Zeszyty Naukowe Instytutu Pojazdów. Warszawa 2010

[2] Tomaszewski F., Tomaszewski S.: Dobór elementów przekładnika ciśnienia i ich wpływ na parametry pracy. Pojazdy Szynowe 4/2014

[3] Norma PN-EN 15611+A1: 2011: Kolejnictwo - Hamowanie - Przekładniki ciśnienia.

[4] Karta UIC 541 - 04: Hamulec. Przepisy budowy różnych części hamulca. Samoczynna zmiana skuteczności hamowania w zależności od obciażenia ładunkiem. Wydanie 3. Listopad 2006.

Fig. 16 shows a general algorithm for the program operation to simulate the relay valve. Fig. 17 shows an exemplary recording of the input data and the final result of the simulation.

Fig. 18 and 19 presents the exemplary courses of the hysteresis loop of the relay valve operation obtained the simulation model with given the resistances to motion being the result of determined forces occurring as a result of the no parallelism of the lever's support (according to Fig. 7 and 8). Comparison of the efficiency obtained from the test results and the efficiency of the simulation model leads to the statement that the simulation model reflects the actual situation with an accuracy to about $98 \%$.

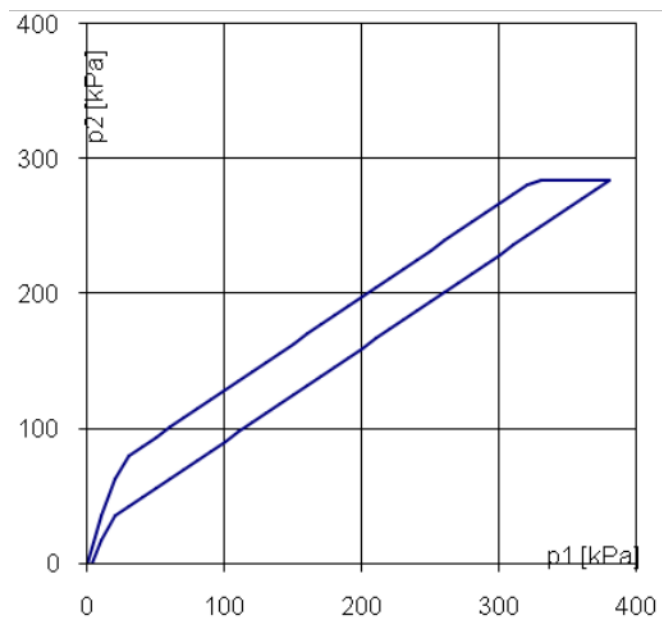

Rys. 19. Przebieg pętli histerezy w modelu symulacyjnym dla oporów ruchu $\mathrm{z}$ rys. 8 . Sprawność $\boldsymbol{\eta}=\mathbf{0 , 8 1 6 8}$

Fig. 19. Course of the hysteresis loop in the simulation model for the resistances to motion from fig 8 . Efficiency $\boldsymbol{\eta}=\mathbf{0 , 8 1 6 8}$

\section{CONCLUSION}

Based on the carried out tests one of causes of occurring the increased hysteresis of relay valve was established, thus narrowing the tolerance of making of the level supports, and providing the satisfactory repeatability of operation of the new and remaining relay valves in operation. The mathematical simulation model of the relay valve was developed, so that it was possible to distinguish the various factors of impact on its efficiency. Thanks to results of tests carried out on the simulation model, a number of other optimization changes in the technical documentation of relay valve, providing the requires sensitivity and hysteresis of relay valves, were introduced.

\section{Bibliography}

